\title{
A Critical Review of Potential Development of Photovoltaic (PV) Systems at Electric Vehicle Charging Stations to Support Clean Energy in Indonesia
}

\author{
Ahmad Maghfuri ${ }^{1, *}$ Cakrawati Sudjoko ${ }^{1}$ Budiawan Sidik Arifianto ${ }^{1}$
}

Yanif Dwi Kuntjoro ${ }^{1}$

\author{
${ }^{1}$ Department of Energy Security, Indonesia Defence University, Bogor, Indonesia \\ *Corresponding author. Email: furymaghfuri@gmail.com
}

\begin{abstract}
Energy needs are always increasing in various sectors of life. Indonesia, which is below the equator, has extraordinary advantages, one of which is its high potential for solar energy. With high sun exposure throughout the year, Indonesia has the potential to use it to generate electrical energy. One of the biggest energy needs is transportation needs. To be in line with the energy mix agenda with energy sustainability, it is necessary to implement the use of clean energy in the transportation sector. Indonesia needs to increase the use of environmentally-friendly vehicles as an action to implement clean energy. The development of electric vehicles is considered appropriate as a solution and the government's efforts to seriously apply it can be seen from the stipulation of Presidential Decree 55/2019 concerning the Acceleration of the Battery Electric Vehicle Program for Road Transportation. The program must be supported by the provision of energy, namely the construction of supporting infrastructure in the form of electric charging stations. Indonesia's geographical condition with the government's and the world's mission in realizing clean energy can be done by using PV as energy to support the availability of electricity at electric charging stations with smart grid integration for land electric vehicles. This study was conducted with a qualitative method using data collection. This has a positive long-term value so that Indonesia's energy development and development goals are in line with the concept of sustainability so that in the future the use of energy in society is the use of environmentally friendly energy.
\end{abstract}

Keywords: Photovoltaic, Electric Vehicle, Charging Station, Clean Energy.

\section{INTRODUCTION}

Electricity is a primary human need, today with the progress of the times, the need for comprehensive electricity in all walks of life from urban to rural areas includes various sectors. Indonesia, which is below the equator, has extraordinary advantages to meet its electricity needs, one of which is having a high potential for solar energy. With high exposure to sunlight throughout the year, Indonesia has the potential to use it to produce electrical energy (Purwanto, 2020). The need for electricity is increasingly complex in more advanced uses, including for vehicle energy supply, namely the transportation sector. The transportation sector continues to grow, private vehicles, both cars, and motorcycles fueled by oil and gas (BBM) continue to increase. Until now, the national energy mix is still dominated by fossil energy. In 2015, oil took a share of $43 \%$ of the total national energy mix, followed by coal $28.7 \%$, gas $22 \%$, and NRE $6.2 \%$ 6. Meanwhile, fuel consumption cannot be met by domestic production, so imports are required. which is expected to continue to increase. This is because the majority of current technologies use fossil energy as their raw material, especially in the transportation sector. On the other hand, electric vehicles as a way out of dependence on fuel consumerism are very hopeful for the energy security of the Indonesian nation in the future. So that the implementation of electric vehicles can effectively reduce the greenhouse effect in the downstream energy management in the transportation sector, making Indonesia a country with clean energy use in the future in a sustainable manner (Matarru, 2020).

Related to the development and development of this energy, of course, facing the challenges of providing 
energy as described by the National Electricity Company (PLN), including clean energy where the electricity sector in Indonesia produces CO2 emissions of 195.9 MTCO2/year. Renewable Energy's contribution is $11.23 \%$. With the development of a Photovoltaic (PV) System, it is hoped that it can help meet future energy needs that are safe and environmentally friendly. Our paper presents a review of the Potential Development of Photovoltaic (PV) Systems at Electric Vehicle Charging Stations to support clean energy which is expected to continue to grow and develop for the progress of development in Indonesia.

\section{METHODOLOGY}

This research was conducted using qualitative methods. Researchers used qualitative data collection techniques as a basic guide. Data collection techniques used secondary data in the form of descriptive analysis from various library references such as books, encyclopedias, scientific journals, newspapers, magazines, and documents. The focus of the library.

\section{DISCUSSION}

The potential for new and renewable energy (EBT) is a non-fossil energy source that is environmentally friendly compared to fossil energy, where NRE has an important role in efforts to reduce the impact of climate change and global warming because NRE is lowemission and sustainable. Solar power is an environmentally friendly energy source. Building a Solar Power Plant (PLTS) with the simplest model, namely placing solar panels (photovoltaic) on vacant land or building roofs to capture sunlight (Modjo, 2019). Indonesia in general has great potential in developing solar energy. The potential of solar energy in Indonesia is $4.8 \mathrm{kWh} / \mathrm{m} 2 /$ day (Taro \& Hamdani, 2020). The development of Photovoltaic as an electric charging station for land electric vehicles is expected to be able to encourage sustainable national energy security. So it is hoped that the acceleration of the application of Electric Vehicle Infrastructure can be one solution. The aspect of industrial independence can also be fulfilled if, in the field of Electric Vehicle Infrastructure, domestic product facilities can be developed, from the provisions if the National Standard Protocol for Electric Vehicle Charging System is applied specifically for Indonesia (Matarru, 2020).

This of course can be used as a source of supporting energy in the development of public electric vehicle charging stations (SPKLU) where the main energy is sourced from PLN. The need for electric vehicle charging station infrastructure is in line with the overall increase in the use of electrical energy. There are several things that we must know in terms of the development of electric vehicle infrastructure, namely about the costs and benefits generated in the development of the supporting infrastructure (Han et al., 2018). Various studies have been carried out on electric vehicle charging stations, $\mathrm{Lu}$ et al., (2014) in their research on the integration and optimization of PV microgrid systems in charging stations, the results show that rationally making a charging station based on a PV microgrid system requires considerable costs. This is due to the need for electricity storage (batteries) as well as the technology used in microgrids to produce and distribute to electric vehicle charging stations. However, the integration of battery usage can smooth out charging spikes at the charging station to reduce the peak to off-peak time. Solar power is now widespread and used everywhere.

To achieve more environmentally friendly transportation of energy supply, solar PV-based charging stations are the most feasible solution. The advantages of combining a solar PV system and EV charging technology can overcome their respective challenges. The integration of solar PV grids with charging stations can reduce charging costs per unit compared to charging based on national electricity grids (A. Verma, 2018). In addition, installing solar PV-based charging stations reduces peak demand on the grid. It also reduces EV dependency on the grid.

Figure 1 Charging station schematic design with AC main bus. Source: G. T. Chandrasa, Et.al., 2020.

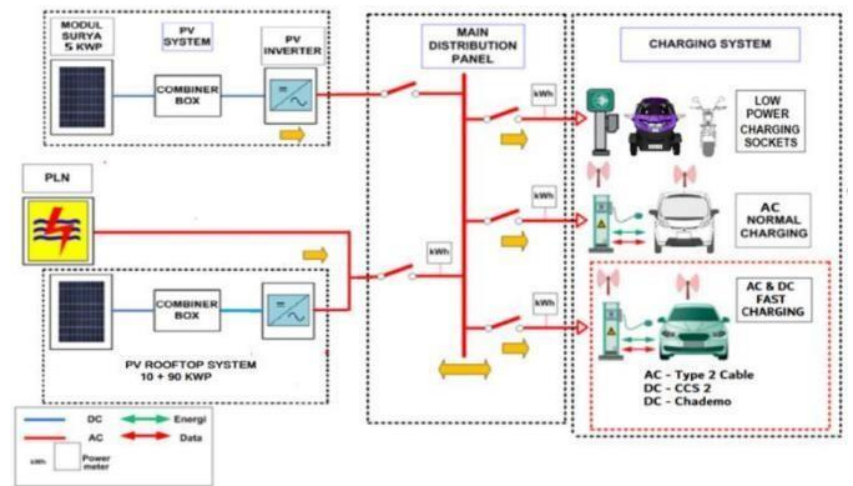

The Indonesian Agency for the Assessment and Application of Technology has designed and built a charging station facility system using a four-wheel EV Fast Charger, which is combined (hybrid) with a photovoltaic system as a Solar Power Plant (PLTS), and PLN grid (G. T. Chandrasa, 2020). This facility itself was inaugurated on December 5, 2018. The schematic design of the charging station system is described in Figure 1. In the main electrical panel, several points can be used for research by installing a digital $\mathrm{kWh}$ meter, which is then sent via modem to the CSMS (Charging) server. Station Monitoring System). 
From the research conducted (G. T. Chandrasa, 2020), it was found that the use of renewable energy in the form of photovoltaic makes it possible to recharge electrical energy in EVs. However, due to limited land, the PLTS canopy roof is only sufficient for the placement of $5 \mathrm{kWp}$ PLTS. When used to recharge KBL with a 16 kWh battery, this PLTS proved to be lacking and its shortcomings were added intelligently with electricity from the PLN network. The solar PV installations are made connected to the PLN grid, and no batteries are added for backup as they can be handled by PLN electricity when needed (line energy storage electricity)

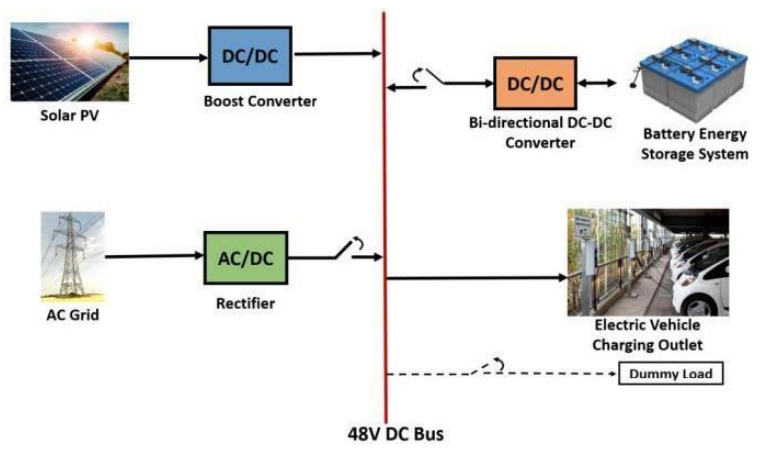

Figure 2 Charging station schematic design with DC main bus Source: T. S. Biya, 2019)

Another design is proposed by Biya and Sindhu,2019 paper which takes an optimal approach to the design and power management of solar electric vehicle charging PV stations and Battery Energy Storage System (BESS) with $\mathrm{AC}$ grid (figure 2). Solar PV acts as the main source to charge all the connected EVs at the charging station. At night there is no power from solar PV, so a battery as an energy storage device is provided to charge the EV connected to the charging station. Whenever there is a shortage of solar power or BESS output to charge the EV, the required amount of power will be drawn from the AC grid to ensure the continuous operation of the charging station throughout the day. The results show that solar charging stations with battery storage systems and additional grid support provide a promising solution to meet all-day charging requirements for all EVs.

The development of PV as an electric charging station is expected to be integrated with the smart grid to be more effective and efficient. Some of the benefits that can be generated include: - Increase efficiency, reliability, and resilience through automation and digitization along the electricity system chain (digitalization), - Increasing active customer engagement into a decentralized system - Increase the penetration of renewable energy through a flexible grid (de-carbonization). To accelerate the development of Electric Motorized Vehicles (KBL) and Public Electric Motorized Vehicle Charging Station (SPKLU) infrastructure, the government has issued Presidential Regulation No. 55 of 2019. This Presidential
Regulation can be used as a frame of reference for building the KBL ecosystem. Although regulations and their derivatives will be made and have been made, as well as socialization, they are not considered sufficient. This means that these efforts need to be carried out in parallel with studies of their implementation and studies to stimulate the development of the KBL ecosystem.

One of the obstacles in increasing the use of electric vehicles in the early stages is the lack of infrastructure for charging electric vehicles, users of electric vehicles find it difficult to charge when they travel long distances. In addition, the price of fast-charging stations (CS) or general electric vehicle battery charging stations (SPKLU) is still relatively expensive and still has to be imported. Therefore, it is necessary to make efforts to master the technology so that it can be made by domestic industries (BPPT, 2020).

To support the realization of the national electric vehicle development program, it is necessary to support the provision of electric vehicle infrastructure. According to data from the Ministry of Industry in 2020, 1,000 units of SPKLU are needed in 2025 and are predicted to increase to 10,000 units in 2050. The development of the SPKLU (General Electric Vehicle Charging Station) is planned to support the target of the availability of 2,200 electric cars in 2025 which is predicted to be increased to 4.2 million units in 2050 (BPPT, 2020). One alternative that can be used to accommodate these needs is the operation of a smart grid-based PV system at the electric vehicle charging station (Kumar, 2019).

The role of the government is very important as a command for the migration of vehicle energy into electric vehicles. The Indonesian government is accelerating the era of electrification of motorized vehicles to be used as road transportation to reduce the production of pollution emissions and imports of fuel oil (Kurniawan, 2020). The government also opens up business opportunities for the private sector to jointly build and make the EV program a success in Indonesia. The construction of Public Electric Vehicle Charging Stations (SPKLU) to SPBKLU (General Electric Vehicle Battery Exchange Stations) have begun to be carried out by SOEs and the private sector (anwardhana, 2021). In total, 100 units of charging stations have been built until January 2021. The SPKLU is spread across 72 locations in Indonesia. This indicates that EV development by the government is serious. However, the current PV integration is not yet optimal. This needs special attention so that the implementation and implementation of $\mathrm{PV}$ and $\mathrm{EV}$ development can go hand in hand and in line with national goals in supporting the use of clean energy in Indonesia.

\section{CONCLUSION}

The development of electric motorized vehicles $(\mathrm{KBL})$ is a big opportunity in implementing clean energy 
in Indonesia. The government's planning and policies in its implementation have also supported the program. However, the application of the use of renewable energy such as PV on the grid system (smart grid) has not been carried out optimally. This needs to be used as a comprehensive plan so that program implementation can run in synergy towards achieving the energy mix, both from the vehicle side and from the supply of driving energy, namely the charging station. The government needs to make special policies so that the program can run optimally so that the public's mindset on clean energy can increase in a sustainable manner

\section{RECOMMENDATION}

The use of PV systems is a renewable and environmentally friendly energy source. The provision of energy for electric vehicles and charging stations must also use environmentally friendly energy sources to remain in line with its main goal, namely a cleaner environment. However, the intermittent nature of solar PV becomes a constraint on continuous energy supply for charging stations. Therefore, it is necessary to apply several technologies that can be managed optimally to produce a sustainable system. So that this PV system can be used to support future energy supplies. In addition, there is a need for support and cooperation from several parties, namely the government, SOEs, the private sector, and researchers in developing and supporting the PV system further. Thus generating policies, strengthening technology, and generating long-term benefits

\section{REFERENCES}

[1] BPPT, Electric Vehicle Charging Stations: TechnoEconomic Studies, Regulations and Standards". Center for Energy Conversion Technology (B2TKE), Agency for the Assessment and Application of Technology, 2020.

[2] Emir, "Mobi Listrik Buat Dorong EBT, kok Listriknya dari Batu Bara?", 2021. https://www.cnbcindonesia.com/news/2021030915 1728-4- 228953/mobil-listrik-buat-dorong-ebt-koklistriknya-dari- batu-bara pln.go.id

[3] Chandrasa, G. T. et. Al, "Photovoltaic energy for smart hybrid fast charging station", In Seminar Nasional Teknologi Bahan Dan Barang Teknik, 2020, pp. 23-28.

[4] Kumar, "PV Based Off-Grid Charging Station For Electric Vehicle”, Elsevier, 2019.

[5] Kurniawan, R, "This is a list of places to charge electric vehicles in Indonesia", 2021. https://otomotif.kompas.com/read/2021/01/07/0712 00515/ini -daftartempat-ngecas-kendaraan-listrik-diindonesia?page $=$ all

[6] Lu, X. et. al, "Multi-objective optimal scheduling of a DC micro-grid consisted of a PV system and EV charging station”, 2014 IEEE Innovative Smart Grid Technologies - Asia, ISGT ASIA 2014, 51277067, 2014. Pp 487-491.

https://doi.org/10.1109/ISGTAsia.2014.6873840

[7] Matarru, "Analysis of Fast Charging System Development for Electric Vehicle Implementation", Indonesian Defense University, 2020.

[8] Modjo, S, "PLN vs. Renewable Energy: Regulation of the Minister of Energy and Mineral Resources regarding the Use of Rooftop Solar Power Generation Systems", Indonesian Journal of Environmental Law, Vol.6(No.1), 2019, pp 19-40.

[9] National Renewable Energy Agency- Distributed Solar Photo Voltaics For Electric Vehicle Charging [Online]. Available: https://www.nrel.gov/docs/fy14osti/62366.pdf

[10] Government Regulation of the Republic of Indonesia Number 79 of 2014 concerning National Energy Security, 2014.

[11] Preetham, G., and Shireen, W., "Photovoltaic charging station for plug-in hybrid electric vehicles in a smart grid environment", 2012 IEEE PES Innovative Smart Grid Technologies, ISGT 2012, 2012 .

$$
\text { https://doi.org/10.1109/ISGT.2012.617 } 5589
$$

[12] Purwanto, "Solar Cell (Photovoltaic/Pv) Solution Towards an Electric Independent Island", Journal of Research and Scientific Works of the Trisakti Yanwardhana University Research Institute, 2020.

[13] Taro, Z., and Hamdani, "Cost Analysis of Household-Scale Roof Solar Power Generation (PLTS)", Journal of Electrical and System Control Engineering, 3(2), 2020, pp 65-71.

[14] Biya, T. S. and Sindhu, M. R., "Design and power management of solar-powered electric vehicle charging station with energy storage system," In 2019 3rd International Conference on Electronics, Communication, and Aerospace Technology (ICECA), IEEE, pp. 815-820, 2019.

[15] Verma, and Singh, B., "A solar PV, BES, grid and DG set based hybrid charging station for uninterruptible charging at minimized charging cost," In 2018 IEEE Industry Applications Society Annual Meeting (IAS), IEEE, 2018, pp. 1-8. 